\title{
Retrospective analysis of 286 Brucellosis cases in the southeast of Turkey
}

\author{
Türkiye'nin Güneydoğusunda 286 Brusellozis vakasının geriye dönük analizi
}

\author{
Recep Tekin ${ }^{1}$, Zehra Çağla Karakoç ${ }^{2}$, Özlem Demirpençe ${ }^{3}$, Fatma Bozkurt ${ }^{1}$, Özcan Deveci ${ }^{1}$, Duygu Mert ${ }^{4}$
}

\section{ABSTRACT}

Objectives: The aim of this study was to evaluate the clinical, laboratory findings and therapeutic features of the patients inhabiting in Diyarbakır, Mardin and Batman province, in Southeastern Anatolia of Turkey.

Materials and methods: In this study, 286 patients with brucellosis, followed in departments of infectious diseases and clinical microbiology between June 2007 and July 2009, were evaluated retrospectively.

Results: One hundred fifty six (55\%) of the patients were female and $130(45 \%)$ were male. Mean age was $32.8+$ 15.3 (range15-78) years. The patients were categorized as acute $(75 \%)$, subacute $(23 \%)$ and chronic $(2 \%)$ brucellosis. Major transmission route was the consumption of unpasteurized fresh cheese. The transport of animals in the region is not controlled. Malaise, fever, myalgia arthralgia and sweating were the most frequently observed symptoms. The most common signs were fever $90.8 \%$, arthritis $54.1 \%$, splenomegaly $18.3 \%$ and hepatomegaly $11 \%$. The most frequent laboratory finding was a high $\mathrm{C}$ reactive protein level (60\%). Diagnosis was made based on the clinical features and positive Rose-Bengal test combination with an initial Brucella antibody titer greater than or equal to $1 / 160$. The most frequently preferred antimicrobial regimen was rifampin and doxycycline combination.

Conclusions: Brucellosis is still an important public health problem in Turkey. The disease has an important morbidity and mortality. Brucellosis should be kept in mind in endemic regions of our country with the symptoms of fever, leukopenia and osteoarticular symptoms. $J$ Clin Exp Invest 2012; 3 (3): 335-339

Key words: Brucellosis, Southeastern Anatolia, Turkey.

\section{ÖZET}

Amaç: Çalışmamızda; Türkiye'nin Güneydoğu Anadolu bölgesinde yer alan Diyarbakır, Mardin ve Batman illerindeki brusellozlu hastaların klinik, laboratuvar ve tedavi özellikleri yönünden değerlendirilmesi amaçlanmıştır.

Gereç ve yöntem: Haziran 2007- Temmuz 2009 tarihleri arasında Enfeksiyon Hastalıkları ve Klinik Mikrobiyoloji Kliniğinde bruselloz tanısı ile izlenen 286 hasta geriye dönük olarak değerlendirilmiştir.

Bulgular: Hastaların 156 (\%55)'i kadın, 130 (\%45)'i erkek ve yaş ortalamaları 32,8 + 15,3 (15-78) idi. Vakaların $\% 75$ akut, \%23 subakut ve \%2'sini kronik olarak gruplandırıldı. Hastalığın bulaşmasındaki en önemli faktörün taze peynir yeme olduğu ve bölgede hayvan hareketlerinin kontrolünün olmadığı belirlendi. Hastalarda en sık rastlanan şikayetler yorgunluk, ateş, kas ve eklem ağrıları ve gece terlemesi idi. Ateş $(\% 90,8)$, artrit $(\% 54,1)$, splenomegali $(\% 18,3)$ ve hepatomegali $(\% 11)$ en sık rastlanan muayene bulgularıydı. Laboratuvarda ise C- Reaktif Protein (CRP) değerinin \%60 yüksek olarak saptanması en sık rastlanan bulguydu. Tanı klinik belirtilerle birlikte pozitif Rose-Bengal ve Brusella tüp aglütinasyon testinin 1/160 ve üzeri olması ile konuldu. Tedavide ise çoğunlukla rifampisin ve doksisiklin kombinasyonu tercih edildi.

Sonuç: Bruselloz hala ülkemizde önemli mortalite ve morbiditeye neden olan bir halk sağlığı sorunudur. Brucella, özellikle endemik bölgelerde, ateş, lökopeni ve osteoartiküler bulguların varlığında ayırıcı tanıda mutlaka akılda bulundurulmalıdır.

Anahtar kelimeler: Brucellosis, Güneydoğu Anadolu, Türkiye.

\footnotetext{
${ }^{1}$ Department of Clinical Microbiology and Infectious Diseases, Faculty of Medicine, Dicle University, Diyarbakır, Turkey ${ }^{2}$ Department of Clinical Microbiology and Infectious Diseases, Şişli Florance Nightingale Hospital, istanbul, Turkey 3 Department of Biochemistry, Batman District Training and Research Hospital, Batman, Turkey

${ }^{4}$ Department of Clinical Microbiology and Infectious Diseases, District Training and Research Hospital, Batman, Turkey

Correspondence: Recep Tekin,

Department of Infections Disease, Faculty of Medicine of Dicle University, Diyarbakır Email: rectek21@hotmail.com Received: 27.07.2012, Accepted: 16.08.2012

Copyright (C JCEI / Journal of Clinical and Experimental Investigations 2012, All rights reserved
} 


\section{INTRODUCTION}

Brucellosis is a zoonosis, which exists worldwide, but it is especially prevalent in the Mediterranean basin including Turkey. Major route of transmission to humans include by ingestion of unpasteurized dairy products of an infected animal. ${ }^{1}$ Disease can be categorized as acute ( $<8$ weeks), subacute $(8-52$ weeks) and chronic (>52 weeks) brucellosis according to the onset of symptoms. Symptoms of acute brucellosis are fever, sweats, malaise, anorexia, headache and back pain, which are nonspecific. In subacute cases undulant fever and muscle-skeletal system symptoms are predominant. In cases with chronic brucellosis, symptoms can recur for long period of time and low-grade fever, neuropsychiatric complaints can be seen. ${ }^{2}$ The diagnosis is made with certainty when Brucella recovered from blood, bone marrow or other tissues. ${ }^{1}$ The rate of isolation ranges from $15 \%$ to more than $90 \%$ depending on the methods used. ${ }^{3,4} \mathrm{~A}$ variety of tests have been applied to the serologic diagnosis of brucellosis, of which are Serum Agglutination test (SAT), Rose Bengal test or ELISA. 5,6

The aim of this study was to evaluate the demographic, clinical, laboratory findings and therapeutic features of the 286 brucellosis cases.

\section{MATERIALS AND METHODS}

This retrospective study included 286 patients who were diagnosed with brucellosis and treated at the Mardin State Hospital, Nusaybin State Hospital and Batman State Hospital Infectious Diseases and Clinical Microbiology clinics between September 2007 and October 2009. Demographic data, clinical symptoms and signs, laboratory findings and therapeutic features of the patients were analyzed from the outpatient unit cards. Patients were categorized as acute ( $<8$ weeks), subacute (8-52 weeks) and chronic (>52 weeks) brucellosis according to the onset of symptoms. The diagnosis based on clinical findings compatible with brucellosis (fever, arthralgia, sweating, malaise, hepatomegaly, splenomegaly, lymphadenopathy, signs of focal disease), supported by detection of positive Rose-Bengal test combination with specific antibodies at significant titers and/or demonstration of at least 4-fold rise in antibody titer in serum samples obtained 3-4 weeks apart. Antibody titers were determined by standard tube agglutination (STA), Brucella coombs test or Brucellacapt assay $(5,6)$. The titers were equal or greater than 1/160 are considered diagnostic in conjunction with a compatible clinical presentation.

During the study period, bacterial isolation was not a routine practice because of the lack of conditions in Mardin, Nusaybin and Batman State Hospitals. X-rays, ultrasonography (USG), computerized tomography (CT), magnetic resonance (MR) imaging, echocardiography, and lumbar puncture were performed in order to examine complications. Relapse was defined as reappearance of symptoms and signs after the completion of treatment in oneyear duration of time. Therapeutic failure was defined as persistence of symptoms and signs attributable to disease after completion of therapy.

Statistical analysis was performed using SPSS. Chi- square test or Fisher exact test were used for categorical variables. The probability value for statistical significance was set as $<0.05$.

\section{RESULTS}

Two hundred eighty six patients were included in the study. One hundred fifty six $(55 \%)$ of the patients were female and $130(45 \%)$ were male. Mean age was $32.8+-15.3$ (range 15-78) years. Most patients are in the $15-20$ years and $21-30$ years age groups (Figure 1).

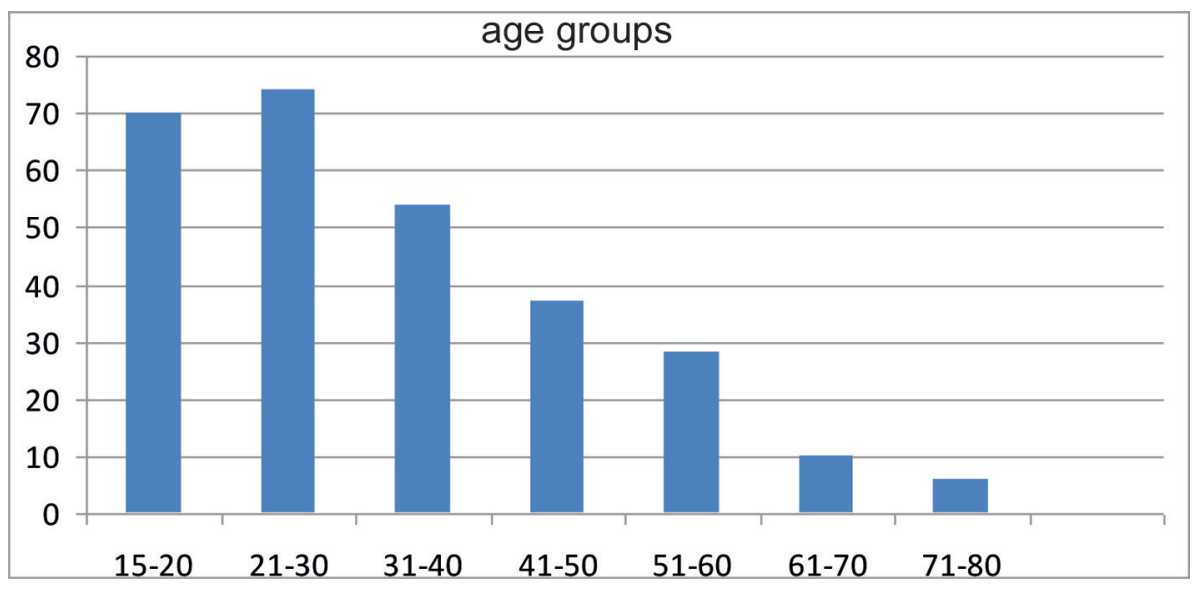

Figure 1. The patients' distribution in age groups. 
The time between the onset of symptoms and clinical presentation ranged from 1 week to 11 months in patients. In terms of clinical forms; $75 \%$ ( $n: 215)$ of the patients were acute, $23 \%$ (n: 66) were subacute, $2 \%(n: 5)$ were chronic. In patients most clinical symptom was fever, which is presented in acute form $95 \%$ (n: 204), 41\% (n: 27) in subacute form, $40 \%(n: 2)$ in chronic form. Other frequent symptoms are night sweating $69 \%$ (n: 198), muscle pain $64 \%$ (n: 183), malaise $63 \%$ (n: 179), and joint pain $\% 62$ (n: 177). Major clinical findings in patients were fever $(79 \%)$ (Table 1$)$.

Table 1. Clinical characteristics and outcomes of the 286 patients with Brucellosis

\begin{tabular}{|c|c|c|}
\hline & $\mathrm{n}$ & $\%$ \\
\hline \multicolumn{3}{|l|}{ Symptoms and signs of patients } \\
\hline Fever & 233 & 81 \\
\hline Night sweating & 198 & 69 \\
\hline Myalgia & 183 & 64 \\
\hline Malaise & 179 & 63 \\
\hline Joint pain & 177 & 62 \\
\hline Lumbar pain & 165 & 58 \\
\hline Sacral pain & 162 & 57 \\
\hline Limitation of movement & 102 & 36 \\
\hline Headache & 96 & 34 \\
\hline Anorexia & 39 & 14 \\
\hline Vomiting & 14 & 5 \\
\hline Abdominal pain & 12 & 4 \\
\hline Icterus & 3 & 1 \\
\hline Scrotal pain & 3 & 1 \\
\hline Unconsciousness & 1 & 0,3 \\
\hline \multicolumn{3}{|l|}{ Physical and clinical findings of the patients } \\
\hline Fever & 227 & 79 \\
\hline Arthralgia & 156 & 55 \\
\hline Hepatomegaly & 92 & 32 \\
\hline Splenomegaly & 69 & 24 \\
\hline Sacroiliitis & 124 & 43 \\
\hline Lymphadenopathy & 12 & 4 \\
\hline Icterus & 3 & 1 \\
\hline Neck stiffness & 1 & 0,3 \\
\hline \multicolumn{3}{|l|}{ Laboratory findings of the patients } \\
\hline \multicolumn{3}{|l|}{ 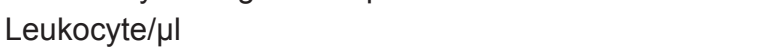 } \\
\hline$<4600$ & 59 & 21 \\
\hline $4600-10200$ & 217 & 76 \\
\hline$>10200$ & 10 & 3 \\
\hline Lymphocytes $\geq \% 40$ & 115 & 40 \\
\hline 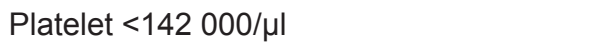 & 83 & 29 \\
\hline Alanine transaminase >35 IU/L & 151 & 52 \\
\hline Aspartate transaminase $>40 \mathrm{IU} / \mathrm{L}$ & 139 & 49 \\
\hline Total bilirubin $>1.2 \mathrm{mg} / \mathrm{dl}$ & 74 & 26 \\
\hline Erythrocyte sedimentation rate $>20 \mathrm{~mm} / \mathrm{h}$ & 162 & 57 \\
\hline C- Reactive protein $>5 \mathrm{mg} / \mathrm{dl}$ & 247 & 86 \\
\hline
\end{tabular}

The others are sacroiliitis (43\%), hepatomegaly $(32 \%)$, and splenomegaly (24\%). Clinical, demographic, laboratory features and outcomes of the 286 cases with brucellosis were summarized in detail in Table 2. Antibiotic combinations used were; rifampin+doxycycline 76\% (n: 217), streptomycin + doxycycline 13\% (n: 38), streptomycin+doxycyc line+rifampin $8 \%$ ( $\mathrm{n}: 24)$, ceftriaxone+rifampin $1 \%$ (n: 3), doxycycline+trimetoprim-sulfamethoxazole (TMP-SMZ) (n: 2), TMP-SMZ+ rifampin + ceftriaxone (n: 1). Major consumption of route was unpasteurized fresh cheese and milk 79\% (n: 225) of patients. Thirty five percent ( $\mathrm{n}: 105)$ of patients were farmers and $16 \%(\mathrm{n}: 46)$ had brucellosis in their family members.

\section{DISCUSSION}

Brucellosis is an endemic zoonosis and a serious public health problem in Turkey. Among high-risk patients in the eastern part of Turkey, seropositivity has been reported to be as high as $27.2 \% .^{7}$ However, the true rates of brucellosis in endemic countries are most probably higher than reported due to deficiencies in its diagnosis or recording. ${ }^{8}$

Brucellosis can occur at any age but it is most common in adolescents and young adults and both sexes are affected equally. ${ }^{9}$ In our study most affected age groups are the 15-20 years, 21-30 years groups but females $(55 \%)$ were slightly more affected than males (45\%). This may be attributed to involvement in the raising of livestock at a younger age and in most of the families particularly housewives take active duty in the raising of livestock in our region. ${ }^{10,11}$

It was detected that at least one epidemiological resource particularly including raising the livestock and consumption the raw milk and milk of products accounts for $76.7-87 \%$ of cases in Southeast and Central Anatolia Regions, where the incidence of the disease is high. ${ }^{12}$ There was a history of consuming unpasteurized fresh cheese and milk in $79 \%(n=225)$ of our patients, farming in 35\% $(n=105)$ and $16 \%(n=46)$ had brucellosis in their family members. Primary transmission route of the disease is consumption of unpasteurized dairy products in endemic countries, whereas in developed countries is frequent more transmission is through the direct contact and the inhalation. ${ }^{13} \mathrm{~A}$ history of raw dairy product consumption was present in $79 \%$ of the cases in our study, which was consistent with epidemiologic studies from Turkey. ${ }^{10,11,14-17}$ A history of livestock raising has been shown for between $14.6 \%$ and $70.3 \%$ of cases in studies carried out in 
Turkey. ${ }^{11,12,14,15,18-21}$ In our study, there was a history of livestock raising in $35 \%$ as accordance with the previous studies from Turkey. In previous reports, a family history of brucellosis has been reported for between $12.6 \%$ and $43 \%$ of cases in Turkey, ${ }^{10,14,15,21}$ and also in $9.6 \%$ in the study by Roushan et al. ${ }^{16}$ from Iran. In our study, a family history was present in $17.8 \%$ of patients. This may be attributed to the presence of larger families in our region.

Brucellosis may appear in four different forms, namely acute, subacute, chronic, and relapse..$^{1,23,24}$ In this study, the acute presentation constituted most of the cases $(75 \%)$, whereas subacute and chronic cases constituted $23 \%$ and $2 \%$ of the cases, respectively; this is in accordance with previous reports. ${ }^{14,25}$ Typically acute brucellosis cases present with chills, fever, fatigue, sweating, weight loss, and back pain. ${ }^{1,23}$ Subacute cases show a protean clinical presentation, although with less severe symptoms compared to the acute form. Patients with the chronic form of the disease usually present with complaints of malaise, nervousness, emotional lability, depression, or generalized musculoskeletal pain. ${ }^{23-28}$ In our study population, fever was most clinical symptom. Other frequent symptoms were sweating, myalgia, malaise and arthralgia. As are available in the literature in our cases, fever was seen as the most clinical finding. That followed arthralgia, sacroiliitis and hepatomegaly respectively. Leukopenia, thrombocytopenia, elevated liver enzymes, and increased CRP were the most prominent laboratory abnormalities seen in acute and subacute cases. Increased ESR and lymphomonocytosis were observed to the same extent in all forms. ${ }^{1,23,24}$

Brucella infection may involve any organ or tissue in the body. Organ involvement can be assigned as focal involvement or as a complication. The most common systems affected are the locomotor, gastrointestinal, genitourinary, hematologic, cardiovascular, respiratory, and central nervous systems. As the largest organ of the reticuloendothelial system, the liver is affected in almost all patients with brucellosis. Liver involvement results in mild to moderate elevation in liver enzymes. ${ }^{17,27}$ In laboratory findings of our patients, liver enzyme elevation was observed in $52 \%$ of the cases.

In conclusion, brucellosis is hyperendemic in Turkey, where the disease is transmitted mainly by unpasteurized milk and milk products. Thus, prevention depends on eliminating the disease from domestic animals and educating people to use pasteurized products.

\section{REFERENCES}

1. Young EJ. Brucella species In: Mandell GL, Bennett JE, Dolin R, eds. Mandell, Douglas and Bennett's Principles and Practice of Infectious Diseases 6Th ed. Philadelphia Churchill Livingstone, 2005:2669-74.

2. http://www.istanbulsaglik.gov.tr/w/sb/bh/bildirimi_zorunlu_hastaliklar/bruselloz.asp

3. Yagupsky P. Detection of brucella in blood cultures. J Clin Microbiol 1999;37(11):3437-42.

4. Ozturk R, Mert A, Kocak F, et al. The diagnosis of brucellosis by use of BACTEC 9240 blood culture system. Diagn Microbiol Infect Dis 2002;44(2):133-5.

5. Al Dahouk S, Tomaso H, Nöckler K, Neubauer H, Frangoulidis D. Laboratory-based diagnosis of brucellosisa review of the literature Part II: serological tests for brucellosis. Clin Lab 2003;49(11-12):577-89.

6. Casao MA, Navarro E, Solera J. Evaluation of Brucellacapt for the diagnosis of human brusellosis. J Infect 2004;49(2):102-8.

7. Ceylan E, Irmak H, Buzgan T, et al. Van iline bağlı bazı köylerde insan ve hayvan populasyonunda bruselloz seroprevalansı. Van Tıp Derg 2003;10(1):1-5.

8. Godfroid J, Cloeckaert A, Liautard JP, et al. From the discovery of the Malta fever's agent to the discovery of a marine mammal reservoir, brucellosis has continuously been a reemerging zoonosis. Vet Res 2005;36(3):313-26.

9. Gürsoy B, Tekin Koruk S, Sırmatel F, Karaağaç L. Bruselloz: 140 olgunun değerlendirilmesi. Klimik Dergisi 2008;21(3):101-4.

10. Gür A, Geyik MF, Dikici B, et al. Complications of brucellosis in different age groups: A study of 283 cases in southeastern anatolia of Turkey. Yonsei Med J 2003;44(1): 33-4.

11. Taşova Y, Saltoğlu N, Yılmaz G, İnal S, Aksu HS. Bruselloz: 238 erişkin olgunun klinik, laboratuvar ve tedavi özelliklerinin değerlendirilmesi. Turkish J Infect 1998;12(3):307-12.

12. Al Dahouk S, Tomaso H, Nöckler K, Neubauer H, Frangoulidis $\mathrm{D}$. Laboratory based diagnosis of brucellosis-a review of the literature. Part I: techniques for direct detection and identification of Brucella spp. Clin Lab 2003;49(9-10):487-505.

13. Yuce A, Alp Cavuş S. Türkiye'de bruselloz: Genel bakış. Klimik Derg 2006;19(3):87-97.

14. Demiroğlu YZ, Turunç $T$, Çalış kan H, Çolakoğlu S, Arslan $\mathrm{H}$. Brucellosis: retrospective evaluation of the clinical, laboratory and epidemiological features in 151 cases. Mikrobiyol Bül 2007;41(4):517-27.

15. Ataman Hatipoglu C, Kınklı S, Tulek N, et al. Bir eğitim hastanesinin infeksiyon hastalıkları ve klinik mikrobiyoloji kliniğinde izlenen 202 bruselloz olgusunun epidemiyolojik verilerinin irdelenmesi. Klimik Derg 2005;18(3):94-8.

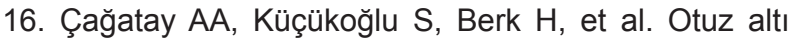
bruselloz olgusunun değerlendirilmesi. Klimik Derg 2002;15(1):19-21. 
17. Demirtürk N, Demirdal T, Erben N, et al. Brucellosis: a retrospective evaluation of 99 cases and review of brucellosis treatment. Trop Doct 2008;38(1):59-62.

18. Savas L, Onlen Y, Savas N, Yapar AF, Aydin M, Onder T. Prospective evaluation of 140 patients with brucellosis in the southern region of Turkey. Infect Dis Clin Pract 2007;15(2):83-8.

19. Örmen B, Türker N, Kaptan F, et al. Brusellozlu 104 olgunun retrospektif değerlendirilmesi. İzmir Atatürk Eğitim Hast Tıp Derg 2004;42(4):173-6.

20. Aygen B, Sümerkan B, Kardeş Y, Doğanay $M$, İnan $M$. Bruselloz: 183 olgunun değerlendirilmesi. Klimik Derg 1995;8(1):13-6.

21. Yüce A, Alp Çavuş S, Yapar N, Çakır N. Bruselloz: 55 olgunun değerlendirilmesi. Klimik Derg 2006;19(1):137.

22. Hasanjani Roushan MR, Mohrez M, Smailnejad Gangi SM, Solemani Amiri MJ, Hajiahmadi M. Epidemiological features and clinical manifestations in 469 adult patients with brucellosis in Babol, Northern Iran. Epidemiol Infect 2004;132(6):1109-14.

23. Doğanay M, Meşe Alp E. In: Topcu AW, Söyletir G, Doğanay $M$, editors. Infeksiyon hastalıkları ve mik- robiyolojisi. $3^{\text {rd }}$ ed., Istanbul: Nobel Tıp Kitabevleri; 2008. p. 897-909.

24. Gotuzzo E, Celillo E, Brucella. In: Gorbach SI, Bartlett JG, Blacklow NR, editors. Infectious diseases. Philadelphia: Harcourt Brace Jovanovich Inc; 1992. p. 1513-8.

25. Aygen B, Doğanay M, Sümerkan B, Yildiz O, Kayabas Ü. Clinical manifestations, complications and treatment of brucellosis: a retrospective evaluation of 480 patients. Med Mal Infect 2002;32(9):485-93.

26. Andriopoulos P, Tsironi M, Deftereos S, Aessopos A, Kopoulos GA. Acute brucellosis: presentation, diagnosis, and treatment of 144 cases. Int J Infect Dis 2007;11(1):52-7.

27. Memish Z, Mah MW, Al Mahmoud S, Al Shaalan M, Khan MY. Brucella bacteraemia: clinical and laboratory observations in 160 patients. J Infect 2000;40(1):5963.

28. Batmaz I, Tekin R, Sariyildiz MA, Deveci Ö, Cevik R. A Case of Brucellosis with simultaneous dactylitis and sacroiliitis. J Med Cases 2012;3(5):304-7. 